\title{
A Malaysian Folklore Game Design As A Tool Of Culture Preservation And Entertainment: Toyol
}

\author{
Mohd Fairuz bin Ali \\ Dept. of Multimedia Design and Animation. \\ Universiti Tunku Adbul Rahman \\ Kuala Lumpur, Malaysia fairuza@utar.edu.my
}

\author{
Ng Perng Jeu \\ Dept. of Multimedia Design and Animation. \\ Universiti Tunku Adbul Rahman \\ Kuala Lumpur, Malaysiangpj@utar.edu.my
}

\begin{abstract}
The study focuses on development of game design based on Malaysian Folklore, Toyol. The objectives of the study are to identify the possibility of applying the Toyol as a main character in a game design and to introduce the characteristics of Toyol through the interactive multimedia platform. The design process is influenced by the discovery of existing contents from local films, literature and novels, myths, fairy tales, folk song and music, animal fables, legends and humorous stories. The study concludes that folklore of Toyol in a form of digital game design could be executed as a digital entertainment tool to channel the understanding of culture, people's belief and knowledge about Toyol.
\end{abstract}

Keywords: Malaysian folklore, digital game, edutainment, popular culture, interactive multimedia technology

\section{INTRODUCTION}

\section{A. General Folklore}

Folklore is all forms of prose narrative, written or oral, which has come down through the years. It may be folk songs, folktales, riddles, proverbs, or other materials preserved in words or in writing. Oyekan Owomoyela, (1979), in his book, African Literature: An Introduction, expresses that there is hardly any phase of tradition and life that is not affected or regulated by some aspect of the folklore, because it is the medium through which the behavioral values of the community, the cumulative wisdom and technology devised by, by gone ages are made available to the present generation and preserved for posterity [1]. Folklore could also be seen as an essential way that cultural knowledge and wisdom is passed from generation to generation as well as from peer-to-peer [2].

\section{B. Folklore in Malaysia}

The Nature of Folklore is getting more important nowadays especially on how we preserve the information and delivering it to the next generation. Folklore is an ideological discipline in which applied to spiritual, verbal and poetical production. Malaysian folklore consists of folk music, folksongs, bardic tales, animal fables, ghost stories, epics, fairy tales, and symbolic lore. Malay folklore refers to a series of knowledge, traditions and taboos that have been passed down through many generations in oral, written and symbolic forms among the indigenous populations of Maritime Southeast Asia (Nusantara). They include among others, themes and subject matter related to the indigenous knowledge of the ethnic Malays and related ethnic groups within the region. The stories within this system of lore often incorporate supernatural entities and magical creatures which form parts of the Malay mythology. Others relate to creation myths and place naming legends that are often inter-twined with historical figures and events. Ancient rituals for healing and traditional medicine as well as complex philosophies regarding health and disease can also be found. [3]

\section{LITERATURE REVIEW}

\section{A. Toyol}

Toyol is a folklore that synonym around South East Asia. It comes with a different name for each region for example in Malay it is called 'Toyol', 'Kwee Kia in Hokkien, Koman-tong (Male) and Koman-lay (Female) in

Thailand, 'Cohen Kroh' in Cambodia, 'Do Yeol' in South Korea, they are called 'Do Yeol' and 'guai zai' in Cantonese. In Malay folklore, a Toyol is a goblin-like creature that steals money and commits other mischief or evil at the instruction of its guardian. It is a mythical creature that is believed to be existence around the real world. According to Dewan Bahasa dan Pustaka, Toyol is a kind of ghost that is labelled as money thief [4].

B. Existence of Toyol in Malaysia

Toyol is truly believed to exist as there were many cases or evidences discovered. This can be supported by the case happened back in 2006 whereby a fisherman from Kampung Kuala Pahang, Malaysia had found the bottle on the shores of a coastal village, believing that what he saw in it was a Toyol. The Toyol was then returned to the local state museum [5]. The museum director at that time described the found Toyol looks like a puppet or marionette, about $20 \mathrm{~cm}$ tall kept in a widemouthed bottle, is cloaked in black and has red eyes and mouth and also contains some sand, a yellow string and slices of onions. 


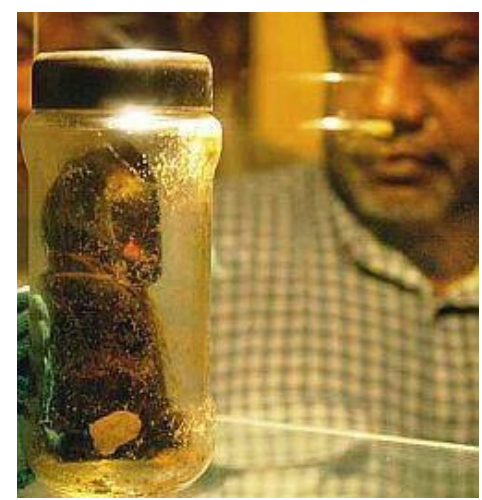

Figure. 1. The toyol sbeing showcased at the Pahang, Malaysia state museum.

(Retrieved from

https://www.thestar.com.my/news/nation/2006/02/24/toyol-drawingthem-in/)

The most recent incident was reported in Malaysia local online newspaper, in 2016. The headline given was 'Kecoh Toyol 'Serang' Kampung' (Toyol creates chaos by attacking a village'). The villagers reported that there was many occasions the money went missing and assumed to be stolen by a thief. Apparently the assumption was wrong when one of the victims encountered the creature right infront of himself. He then describe the creature which is referring to toyol was in green color [6].

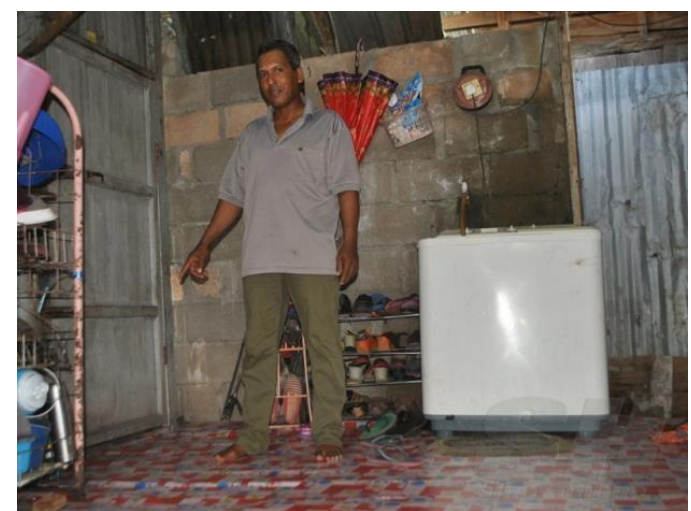

Figure. 2. The villager pointing out at the spot where the toyol makes its appearance

(Retrieved from http://www.sinarharian.com.my/semasa/kecohtoyolserang-kampung-1.583386)

\section{Digital Games and Learning}

It is proven that digital games have been very demanding in the market and all of them have been designed in almost every platform such as $2 \mathrm{D}$ and $3 \mathrm{D}$ console games, computer games, Ipad, Iphone, mobile phone and others. The contribution of digital games is not only on the establishment of fun and entertainment but it is also agreed that it does contribute to the society as an educational tool or so called 'edutainment' even though it is not the main objective or purpose of the digital games. For example kids might learn on mathematic or increase their memory level by playing simple puzzle games. The same goes to other genres of game such as actions and adventure games where these types of games require players to use their brain to come out with strategies and at the same time enable them to polish their creative thinking in order to accomplish every level.
Besides contributing towards the education area, digital games can also have the potential to build awareness, teach, train, mobilize and engage people in advancing positive social change [7]. A game called "Food Force" is a perfect example on how games can be a platform to build and develop positive social behavior changes. Food Force is a game that teaches children about the logistical challenges of delivering food aid in major humanitarian crisis [8].

As far as digital games are encouraging positive values towards society and social changes is concern, digital games also play its role towards cultural preservation and appreciation as well. By looking at the positive aspect, the idea is not to replace the actual value for specific cultural or traditional value but it is mainly to focus in educating and encouraging people to learn more about them. As for example, Malaysian traditional games have been designed in a form of digital game produced by local teams. The name given to that particular game was 'Seremban Stone' and the game play requires player to constantly click on the increasing layers of stones to destroy and crush them [9].

Another example of a Malaysian traditional game that has been designed into a digital game is Congkak named 'Congkakcraze'. The game is designed for iPhone platform where it brings the culture and heritage of Malaysia to a modern platform. The objective of this game is for players to capture more marbles than the opponent.

Besides cultural value, digital games also have contributed towards preserving historical events. An example of a historical event is the Pharaoh or so called "Lord of the Two Lands" and High Priest of Every Temple", a rituals and the most powerful person in ancient Egypt who was the political and religious leader of the Egyptian people (10). Pyramids of Giza, Cheops, Chephren and Mycerinus were all built under the leadership of the Pharaoh (11). Based on the above historical event, a digital game has been developed and designed called "Pyramid Bloxx". This is a game which requires player to guide blocks up mining shafts to build the monuments and pyramids (12).

\section{METHODOLOGY}

\section{A. Preliminary Questionnaire}

Preliminary test through a questionnaire has taken place which acquired sampling of 50 respondents. It was identified that, only $20 \%$ respondents know the existing of Malaysia folklore, Toyol and only $15 \%$ of respondents know the background, history or myth of Toyol. The higher vote on why Toyol is not popular nowadays is because of there are not enough medium of education presenting this folklore which is by $66 \%$. Other factors also contributed and $20 \%$ of the respondents claimed that it is just a myth and $12 \%$ stated that it is because of the modern era that we are living in now. Total of $90 \%$ respondents claimed that they have never came across any topic of Toyol in the media which is very educating and only $10 \%$ respondents answered 'yes'. Based on the response received, most respondents with $94 \%$ agreed that digital game is one of the appropriate/best medium to be designed as a medium to introduce, educate and 
encourage people to find out more about this folklore. 82 $\%$ of respondents believe that medium of Toyol in a form of digital game will receive positive feedbacks and response. Based on the analysis that has been performed, it is clear that Malaysian folklore Toyol is lacking its popularity as there are number of respondents who do not know anything about the background of Toyol even though it has already became one of the popular cultures in Malaysia. Therefore the idea of having Toyol in a form of digital game could be a platform to educate and to encourage people to know more about the Toyol and to present the its unique characteristics into a digital game art styles.

\section{B. Current Popular Culture of Toyol in Digital Game}

Few case studies had been conducted and found out that there are three existing Toyol related game application in the Google Play Store.

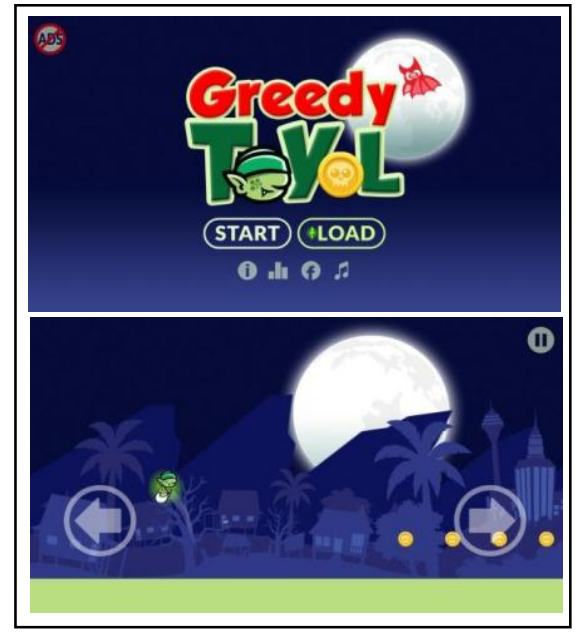

Figure. 3. The main menu and user interface of game application called Greedy Toyol.

The game play requires player to control the main character which is Toyol, to steal as much money from the village by avoiding some obstacles such as pitfalls, traps and enemies.

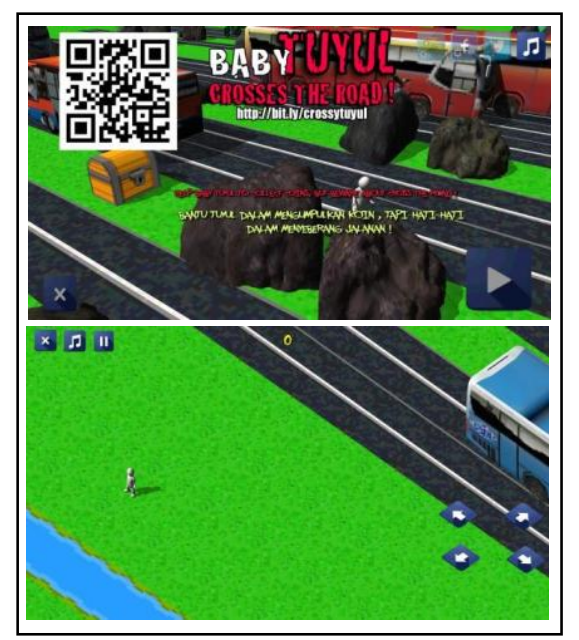

Figure. 4. The main menu and user interface of game application called Baby Tuyul Crosses the Road.

This game requires player to control the main character, Toyol to colect coins in the middle of busy roads as obstacles such as bus, motorbike, car and other vehicles might end the game.

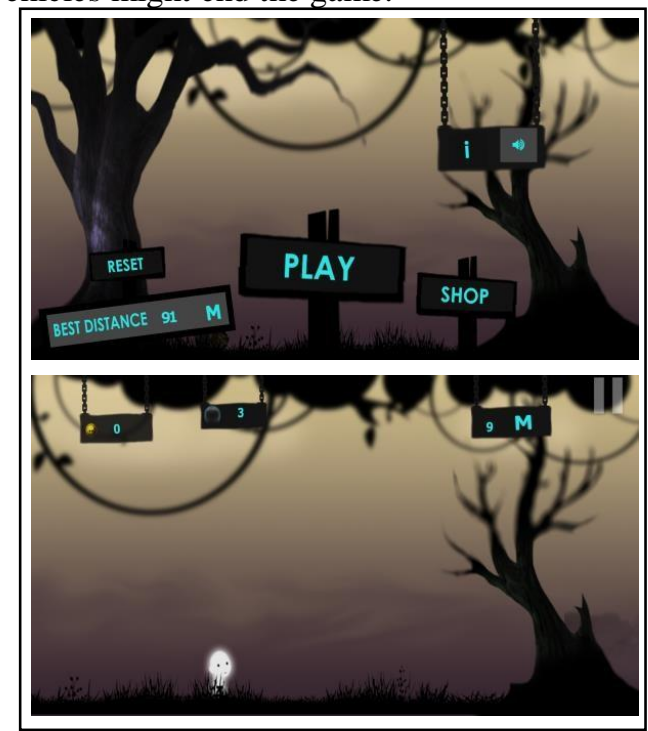

Figure. 5. The main menu and user interface of game application called Tuyul the Adventure

Like other Toyol games introduced, this game requires player to get coin as much as possible. With the amount of coins collected, player then can upgrade the character by buying body protector or even to change the Toyol character.

\section{Current Popular Culture of Toyol in Other Media}

Recent film involving Toyol as one of the main characters could be seen in a film called Alamak...toyol!. It is a horror comedy genre film produced in Malaysia back in November 2011. It is a story about a man seeking a Tok bomoh (Shaman) in a proposition to make him immediately becoming rich.

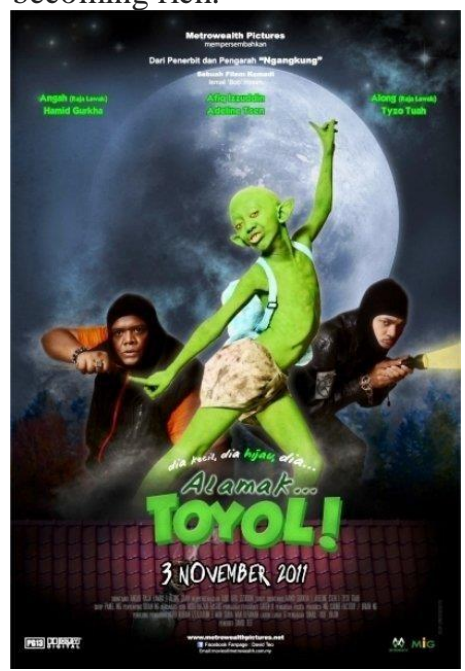

Figure. 6. Alamak...toyol! Film Poster

There is also a short animation work called TOYOL produced by Celoop Production that has becoming hit on Youtube channel which had already reached more than four million views. This media was published in 2013 . 


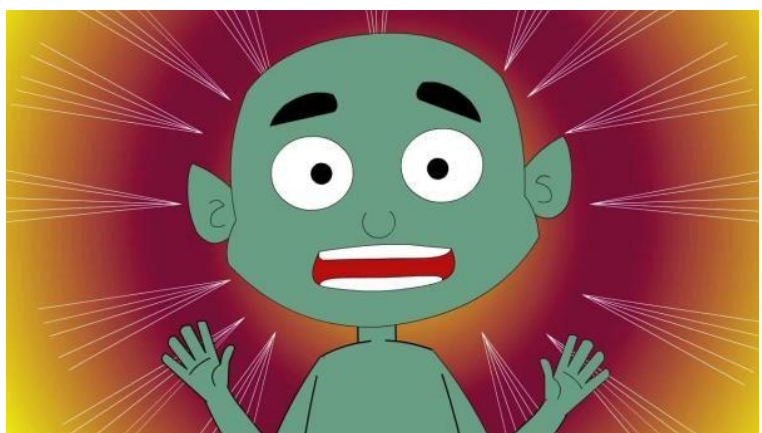

Figure. 7. Video Poster for TOYOL Animation

Apart from that we could also find toyol been used in a song such as Toyol by the late Dato' Sudirman Haji Arshad a Malaysian singer and a songwriter before it was re-introduce with a new version with some modification of the tempo by a famous Malaysian TV celebrity and entertainer Datuk Haji Aznil bin Haji Nawawi.

\section{“toyol dia datang padaku berlari-lari tolong ke mana ku kan pergi toyol kenapa pula aku yang engkau cari tolong rupanya hodoh huwah huwah huwah huwah \\ kepala botak matanya terbeliak giginya bertaring merata-rata ee seramnya kumelihat rupanya melambai-melambai ketawa pula"}

Above is part of the lyrics that can be found in Toyol song that is mainly describing the characteristics of Toyol such as ugly face, bald, big round eyes, scary lookand-appeal and spooky laugh sound.

\section{Proposed Game Work Flow}

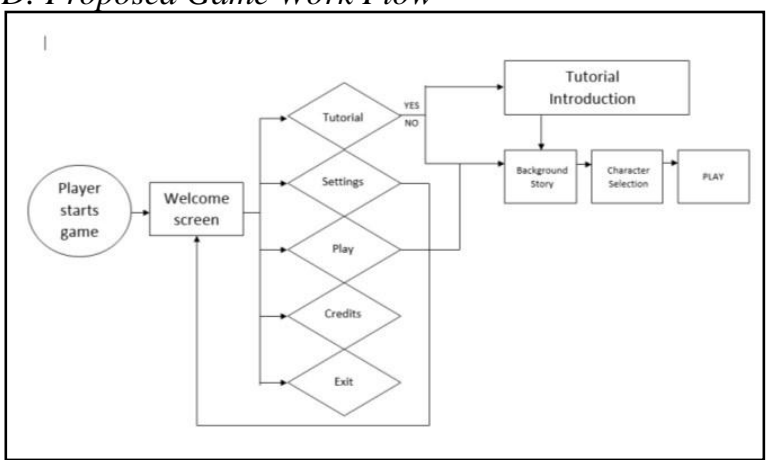

Figure. 8. Work flow for Toyol Attack game design

\section{E. Game Design Ideation}

The game is named as Toyol Attack. The main game emotions will be set as Easy Fun Mechanics, one out of Four Fun Key as described by Nicole Lazzaro [13]. Toyol Attack will provide players to have an iconic situation that will be filled with cute and fun-look characters with a Malaysian village scenes background. The main idea is to provide a space for the players to immerse in the game and to explore ways for them to continuously increase their score.

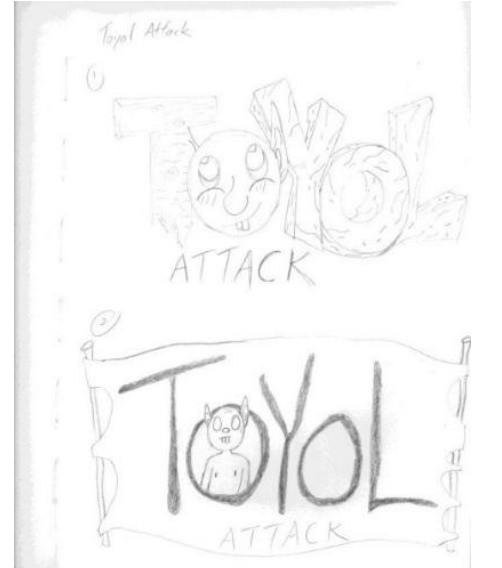

Figure. 8. Sketches on Toyol Attack for Main Menu User Interface

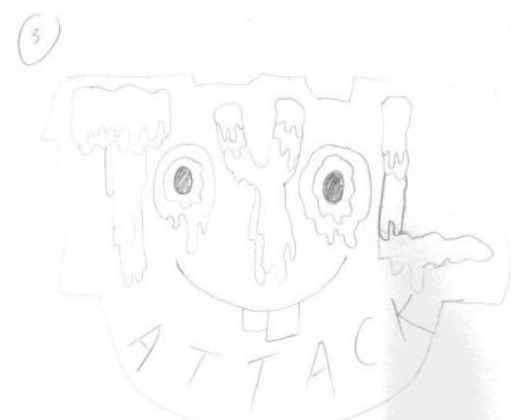

Figure. 9. Sketches on Toyol Attack for Main Menu User Interface

\section{CONCLUSIONS}

This research paper is still a work in progress. We would be hoping to embark on the next stage which is on the game designs in the near future. Main focus will be directed to the original objectives as set, mainly concentrating on the edutainment value of Toyol in a form of digital game application to act as a tool to promote and to enrich Malaysian folklore and indirectly can serve as a platform to preserve Malaysian culture as a whole through the game play and designs of Toyol Attack videogame that is about to be developed.

\section{ACKNOWLEDGMENT}

We would like to thank our family members for the never ending moral support and encouragements and we would like to show our gratitude to REKA 2018 conference committee members for organizing and managing this platform for us to share our research paper creative ideas.

\section{REFERENCES}

[1] Oyekan Owomoyela, African Literatures: An Introduction, Crossroads Press, 1979.

[2] Simon J.Bronner, Meaning of Folklore: The Analytical of Ellen Dundes, University Press of Colorado, Utah State, University Press, 2007.

[3] Moore, Wendy, This is Malaysia, New Holland Publishers, 1995.

[4] Kamus Dewan, p.1711, Kuala Lumpur, 2005.

[5] Toyol Draw Them In, https://www.thestar.com.my/news/nation/2006/02/24/toy ol-drawingthem-in/ 
[6] Kecoh Toyol Serang Kampung,

http://www.sinarharian.com.my/semasa/kecoh-toyolserangkampung-1.583386

[7] For A Better World: Digital Games And The Social Change Sector,

http://www.gamesforchange.org/whitepaper.pdf

[8] Food Force http://www.wfp.org/how-tohelp/individuals/food-force

[9] Seremban Stone,

http://simplygames.tumblr.com/post/636950652/intervie w-withnazmi-the-main-mind-behind-the-facebook

[10] Pharaoh: Lord of Two Lands, http://www.ancientegypt.co.uk/pharaoh/home.html

[11] Kenseamedia, http://www.kenseamedia.com/december/pyra2.htm

[12] Sidetoplay http://www.slidetoplay.com/story/pyramidbloxx-review

[13] Nicole Lazzaro, "Understand Emotions" pp.3-47, Beyond Game Design, Nine Steps Toward Creating Better Videogames, Charles River Media, 2009. 